\title{
Communication Strategy Development of LPP TVRI in Implementing Nawacita and Sustainable Development Goals
}

\author{
${ }^{1}$ Rizky Wulan Ramadhani, ${ }^{2}$ Fajar Rizali Rakhman, ${ }^{3}$ Edy Prihantoro \\ Universitas Gunadarma, Jalan Margonda Raya No.100, Depok, Jawa Barat, Indonesia. \\ E-mail: 'rrizkywulan@gmail.com, ${ }^{2}$ fajarizalir0507@gmail.com, ${ }^{3}$ edipri@gmail.com
}

\begin{abstract}
Indonesia signed the Sustainable Development Goals (SDGs) in 2015. Joko Widodo and Jusuf Kalla proposed Nawacita as a national development goal that must be achieved. Nawacita and SDGs have similarities that involve mass media. TVRI has an extensive network to implement Nawacita and SDGs through a development communication strategy as communication planning and communication management in disseminating messages to invite the community to be involved in development. This study aims to determine the development communication strategy of TVRI in implementing Nawacita and SDGs. Qualitative research methods by conducting interviews and documentation of various sources. From the research results it is known that the media can help to implement Nawacita and SDGs. In this case, TVRI as media that participates in helping the success of the government's role in implementing Nawacita and SDGs in Indonesia using development communication strategies, namely: media-based strategy by using national and local stations, Monitor magazine,newmedia (websitewww.tvri.go.id, Instagram@tvrinasional,Twitter@ TVRINasional, Facebook TVRI Nasional, Youtube TVRI Nasional and the TVRI Klik application), instructional design strategies (internal and external training), participatory strategies (audience journalism and institutional visits) and marketing strategies (programs and collaborations) that are tailored to the values of Nawacita and SDGs.
\end{abstract}

Keywords: Nawacita, SDGs, Development Communication Strategies, TVRI

\section{INTRODUCTION}

In September 2015, the United Nations held its 70th general session in New York United States to discuss global development. A total of 193 heads of state and world government were present to agree on a new universal development agenda as contained in a document entitled Transforming Our World: the 2030 Agenda for Sustainable Development - containing 17 Goals and 169 Targets that apply from 2016 to 2030 (Panuluh \& Fitri, 2016). The document is known as the Sustainable Development Goals (SDGs) which is part of the 2030 Agenda.

The SDGs are a continuation of the Millennium Development Goals (MDGs) agenda (Arianto, 2019). The MDGs are a UN development agenda that was agreed upon in 2000. About 70 percent of the total indicators measuring the MDGs target has been achieved by Indonesia (Said et al., 2016). After the end of the MDGs in 2015, the United Nations signed the SDGs as a global development goal. SDGs have differences from MDGs, especially in the process of setting goals to be achieved. In the process, the MDGs also had weaknesses because the preparation and implementation were exclusive and very bureaucratic without involving the role of non-government stakeholders, such as Civil Society Organizations, Universities / Academics, the business and private sectors, and other groups (Panuluh \& Fitri, 2016). These weaknesses are corrected in the implementation of the SDGs which prioritizes multi-stakeholder cooperation.

Indonesia as one of the countries that have agreed on the implementation of sustainable development goals 
(SDGs) is committed to the successful implementation of the SDGs through various activities and has taken strategic steps (Said et al., 2016). These steps include mapping SDGs goals and targets with national development, mapping data and indicators, compiling operational definitions for each SDGs indicator, ratifying Presidential Regulation Number 59 of 2017 concerning Implementation of Achieving Sustainable Development Goals, and preparing national action plans and regions in the context of implementing the SDGs. The government wants to ensure that the implementation of the SDGs program is carried out with a transformative spirit and no one left behind (Panuluh \& Fitri, 2016). For this reason, the Government includes various non-government stakeholders to be involved in the implementation of SDGs, such as civil society groups, academics, philanthropies, and business actors (Angelica \& Nurhajati, 2019).

Indonesia's medium-term national development priorities have been mutually agreed upon in the National Medium-Term Development Plan (RPJM). Although the 2015-2019 RPJMN has been formulated since 2014, many of the SDGs targets are already included in national development priorities (Said et al., 2016). Apart from that, the Jokowi-JK government's Nawacita program has also been mapped with the objectives of the SDGs. Nawacita itself is Joko Widodo's vision, which is a reflection of President Soekarno's Trisakti thoughts (Arianto, 2019). Nawacita was initiated to create an Indonesia that is politically sovereign, economically independent and has a cultural personality, which is organized into nine agendas that are in line with the SDGs. The alignment of the Nawacita agenda and the SDGs can be seen in TABLE 1

SDGs and Nawacita developed agendas that must be implemented locally and nationally. Given the scope and ambition of the SDGs, it is clear that governments can not achieve that agenda alone (ACSC, 2016). The 2030 Agenda states that to ensure its implementation, a revitalized global partnership is needed, as an intensive global engagement that brings together governments, the private sector, civil society, the UN system and other actors (Pardo, 2018). Jalal stated that every stakeholder who wants to get involved in the SDGs needs to get adequate knowledge about the SDGs in the context of understanding the details of the SDGs Goals and Targets, especially those relevant to their respective roles (Angelica \& Nurhajati, 2019).

One of the stakeholders that must be involved in implementing the SDGs is the media, either mass media or new media. Media is a means of communication for the community, which is located between two parties as an intermediary or liaison (Khatimah, 2018). In general, mass media, including new media, will inform and report various government policies if they are implemented openly, transparently and continuously (Angelica $\&$ Nurhajati, 2019). The new media and ICT in general are seen as a means to speed up and accelerate development if applied properly (Kumar \& Tyagi, 2017). This idea prioritizes the main role of mass media and ICT in creating awareness which aims not only to expand access to information but also to contribute to achieving the SDGs (Elizabeth \& Olayemi, 2020).

On the developing process, mass media has a role that can determine and provide a deeper understanding of something for a developing society (Hendra, 2019). The media have a significant role to inform and educate, to provide a platform for public discussion, to serve as the catalyst for citizens' empowerment and to assist to hold authorities to account (Irwansyah, 2018). 
Rizky Wulan Ramadhani, dkk. Communication Strategy Development of LPP TVRI...

TABLE 1. Alignment of Nawacita and SDGs

\begin{tabular}{ll}
\hline No. & \multicolumn{1}{c}{ Nawacita } \\
\hline 1. Nawacita 1: Bringing the State Back to Protect the Goal 3, 10, 16, 17 \\
Nation and Providing Security to All Citizens \\
2. Nawacita 2: Making Government Always Present by Goal 16 \\
Building Clean, Effective, Democratic, and Reliable \\
Government Governance \\
3. Nawacita 3: Developing Indonesia from the Outskirts Goal 1 - 11 \\
by Strengthening Regions and Villages in a Unitary \\
State \\
Nawacita 4: Rejecting Weak States by Reforming a \\
Corruption-Free, Dignified, and Reliable Law En- \\
forcement System \\
5awacita 5: Improving the Quality of Indonesian Goal 1 - 6 \\
Human Life \\
6. Nawacita 6: Increasing People's Productivity and Goal 1 - 10 \\
Competitiveness in the International Market So that \\
the Indonesian Nation Can Advance and Awaken \\
with Other Asian Nations \\
7. Nawacita 7: Realizing Economic Independence by Goal 1 - 5, 8, 9, and 12 - 15 \\
Mobilizing Strategic Sectors of the Domestic Econ- \\
omy \\
8. Nawacita 8: Carrying out a National Character Rev- Goal 3 - 4, and 11 \\
olution \\
Nawacita 9: Strengthening Diversity and Strengthen- Goal 5, 10, 16, 17 \\
ing the Indonesian Social Restoration
\end{tabular}

Nawacita and SDGs as national and global development activities must be widely disseminated through the use of mass media so that they can be applied in society. The Indonesia Climate Change Trust Fund (ICCTF) states that in the process of implementing Nawacita and the SDGs, the mass media plays a role in 1) disseminating and advocating for the community; 2) providing program facilities in the field; 3) building public understanding; 4) monitoring of implementation.

One of the mass media that plays an important role in the development process in Indonesia is the Public Broadcasting Institute Televisi Republik Indonesia (LPP TVRI). TVRI is a public broadcasting institution, one of the state- owned national televisions and the first television that can broadcast in Indonesia, which has a major influence in providing useful development information for the community (Ningsih, 2017). TVRI was founded on August 24, 1962 based on the Decree of the Minister of Information of the Republic of Indonesia No. 20 / SK / VII / 61. TVRI is located at Jalan Gerbang Pemuda No. 8 RT.1 / RW.3, Gelora, Tanahabang, Kota Jakarta Pusat. TVRI broadcasted the opening of the 4th Asian Games at the Bung Karno Sports Arena Main Stadium as the first broadcast.

TVRI works according to the function of television, namely providing information services, education and healthy entertainment, social control and adhesive, and preserving the nation's 
culture for the benefit of all levels of society through the implementation of television broadcasting that reaches all areas of the Unitary State of the Republic of Indonesia (Ningsih, 2017). Carrying out this function, TVRI maximizes broadcast programs that are able to motivate and empower people which are packaged in various platforms with modern technology and applied appropriately. Internally, TVRI pays more attention to employees by providing training so that they become qualified, competent, creative and ethical human resources who reflect diversity.

In 2005 based on the Government Regulation of the Republic of Indonesia Number 11 of 2005 concerning the Implementation of Public Broadcasting Institutions, TVRI's status became a Public Broadcasting Institution (Lembaga Penyiaran Publik/LPP). The regulation explains that LPP is a broadcasting institution in the form of a legal entity established by the state which must be independent, neutral, non-commercial and provide services for the benefit of the community. In carrying out this function, the content broadcasted by TVRI must contain at least $60 \%$ of domestic broadcasts which provide protection and empowerment to special audiences such as children.

As government television, TVRI is actively involved in disseminating information about Nawacita and the SDGs that can be followed by the public so that the audience can be involved as development actors. Information is something that is fundamental to knowledge, and an educated and knowledgeable population is a resident who experiences empowerment and therefore can participate in population affairs, social development, and progress (Suri, 2019). In addition, the information that is widely owned by the community has made the community as a world community that can participate with various abilities (Hendra, 2019).

The role of the media in an effort to disseminate information related to SDGs has been studied by Irwansyah in a study entitled How Indonesian Media Deal with Sustainable Development Goals. The results of the study were that not all SDGs points were well informed, only a few points were selected based on the concerns of policymakers. Irwansyah researched online media that had print media and online media that did not have printed media. In this study, Irwansyah focused on the agenda-setting carried out by Tribunnews, Tempo and several other media by analyzing using keywords such as "Sustainable Development Goals", "Sustainable development" and "Sustainable development goals". The difference between this research and the research conducted by the researcher lies in the type of media studied are the research method and the object to be studied where the researcher does not only focus on the products of a mass media related to the spread of Nawacita and SDGs.

The role of the media in disseminating SDGs information has also been studied in the research of Sustainable Development - A poorly Communicated Concept by Mass Media. Another Challenge for SDGs? Conducted by Svatava Janoušková, Tomáš Hák, Vlastimil $\mathrm{Ne}^{`}$ cas and Bed rich Moldan. The result of the research is that the media focus on certain issues such as climate change and gender equality but forget about other issues such as sanitation, resulting in an uneven distribution of information. This study uses keywords to find out how often the media disseminates information related to SDGs. The difference between this research and the research conducted by the researcher lies in the media used, the method used and the object to be studied where the researcher does not only focus 
on the products of a mass media related to the spread of Nawacita and SDGs.

Meanwhile, research related to development communication strategies in implementing Nawacita and SDGs was studied in the research on the Development Communication Strategy of the Bojonegoro Regency Government in Implementing Nawacita and the Sustainable Development Goals conducted by Rizky Wulan Ramadhani and Edy Prihantoro. The result of this research is that the Bojonegoro Regency Government implemented four strategies in realizing Nawacita and SDGs in Bojonegoro. This study focuses on the development communication strategy undertaken by local governments. Research conducted by researchers focuses on the role of the media which has the same role in the effort to realize Nawacita and the SDGs in Indonesia.

Based on the research above, the development communication strategy carried out by the media is important in disseminating information so that the public is active in realizing Nawacita and the SDGs. The development communication strategy can be interpreted as planning communication and communication management in the dissemination of development messages to invite the community to be involved in the development process (Ramadhani \& Prihantoro, 2020). The purpose of using a development communication strategy is to ensure that the community is actively involved in implementing Nawacita and SDGs.

There are several development communication strategies put forward by the Academy for Educational Development (AED), namely: 1) Strategies Based on the Media Used (Media Based Strategy); 2) Instructional Design Strategies; 3) Participatory Strategies; and 4) Marketing Strategies. Media Based Strategy is a strategy that uses certain media that is tailored to the needs in an effort to get the public to be involved in the development process. This strategy uses mass communication media, interpersonal communication (face to face) and social media. According to DeVito, the function of influencing is considered the most important function of mass communication (Qudratullah, 2016). Face-to-face communication can easily persuade interlocutor because of the influence of other communications and the influence of their environment (Azhar, 2017). In social media, interpersonal communication and mass communication are fused into one (Azhar, 2017). Instructional design strategies are used by educators who focus on individual learning as the main goal. In the context of learning, instructional design can be interpreted as a systematic process for solving learning problems through the planning process of learning materials and activities that must be carried out, planning learning resources that can be used and planning for evaluation of success (Azhar, 2017). Participatory strategies take advantage of community collaboration to carry out the development. Community support for the implementation of development is one of the factors that can determine the success and failure of any development program (Surahmi \& Farid, 2018). Marketing strategies use a marketing approach but do not only focus on profits but emphasize the needs and desires of consumers.

TVRI's development communication strategy on implementing Nawacita and SDGs can be researched using the Innovation Diffusion Theory popularized by Everett M. Rogers in 1983. Rogers defines diffusion as a process where innovation is communicated through certain channels within a certain period of time among members of a social system (Surahmi \& Farid, 2018). The process of communicating this innovation 
raises a degree of risk that has an impact on receiving messages by the public, not all of whom can accept renewal. An innovation will bring pros and cons in society. According to Rogers and Shoemaker in the spread of innovation there are main elements, namely: 1) Innovation; 2) Communication Channels; 3) Duration; and 4) Social System (Putri, 2017).

Innovation is defined as an activity that includes the entire process of creating and offering services or goods that are new, better or cheaper than previously available (Putri, 2017). The definition of innovation is not limited to new things, innovation can also be interpreted as old knowledge, but someone has not yet decided to accept or reject it. In spreading innovation, a communication channel is needed. Rogers defines a communication channel as "the means by which messages can be received from one person to another" (Istiati, 2016). Rogers and Shoemaker stated that mass media is more effective at creating knowledge about innovation (Putri, 2017). The dissemination of innovation takes a long time because it passes through several stages such as the knowledge stage, the persuasion stage, the decision stage, the implementation stage and the confirmation stage. The process of adopting innovation is carried out by individuals and then applied in a social system where the individual is located. The innovation applied in a system is better (more innovative), efficient and effective.

Nawacita and SDGs are not innovations when viewed from the development messages they wish to convey. However, Nawacita and the SDGs are an innovation in an effort to disseminate them to the community wrapped in new terms and a more active effort to introduce them so that people choose to implement them. The new terms used include Mental Revolution, No One
Left Behind, and the multi-stakeholder approach.

Based on the explanation above, the researcher conducted a study entitled Communication Strategy Development of LPP TVRI in Implementing Nawacita and Sustainable Development Goals to find out the development communication strategies used by TVRI in carrying out its role as a mass media on implementing Nawacita and SDGs.

\section{METHOD}

This study uses a qualitative methodology with a descriptive research design in the form of written or spoken words of people and their observed behavior (Bogdan and Trailor in Astuti, 2017). The results of observing this behavior are a form of consequence of human activities which are constructed in the form of knowledge and cannot be justified as a permanent truth, but the problem is always changing. (Guba, 1990 in Samatan, 2017: 133).

Thedatausedinthisstudyare primary data obtained from direct interviews by observing, taking notes, listening, seeing and asking research subjects about the development communication strategies used by TVRI in an effort to implement Nawacita and SDGs. This data was obtained from Ardison, as the Head of the TVRI Research and Development Center for Program and News Studies, on Friday, 17 January 2020 in the TVRI Training Room. To strengthen primary data findings, secondary data is needed to complement data on field facts, such as literature books, journals, articles, reports, and internet sites relating to the research being carried out.

The data that has been obtained are then processed by (1) data reduction to select and simplify the data so that it becomes concise from the results of the interview, (2) presentation of the data, after the data is simplified and summarized, it 
is formed into a narrative so that it is easy to understand what is happening based on the problem, ( 3 ) drawing conclusions / verification, which is intended to take the essence of a problem which will get a finding from the research of the Communication Strategy Development of LPP TVRI in Implementing Nawacita and Sustainable Development Goals that have gone through the process of data collection, data reduction, and data presentation (Miles and Huberman in Nurwandah \& Badriah, 2020).

\section{RESULTS AND DISCUSSION}

Strategy Based on the Media Used (Media Based Strategy) by TVRI

A strategy based on the media used is the strategy used to spread the message of development through the used media. The used media are usually mass media such as television, radio and newspapers as well as news media such as social media and website. Media is a communication channel used to spread innovation to society within a certain period of time.

TVRI as a government media partner is the station with the widest coverage with 365 transmitter locations consisting of 378 digital analog transmitters and 68 digital transmitters. This amount allows TVRI to sail in the $3 \mathrm{~T}$ (frontier (terdepan), outermost (terluar) and underdeveloped (terbelakang)) areas in Indonesia. This number is far superior to other television stations which only have transmitters under 100 units. TVRI broadcasts 24 hours nationally and in the regions through 29 local stations that can reach $68 \%$ of the population or reach more than 200 million people in Indonesia. TVRI broadcasts also reach the Sabang border to Merauke and Miangas to Rote. The existence of central TVRI in Jakarta is supported by various local TVRI stations that broadcast various information, education and entertainment and prioritize local wisdom of the local area. The list of local TVRI stations is shown in TABLE 2.

National and local TVRI stations consistently provide informative, educational and entertaining shows that have public interest value which are packaged in the form of features that last 30 minutes to an hour and are broadcast every day. In distributing Nawacita and SDGs, TVRI packaged them in a pattern tailored to the audience's interests and adapted to the TVRI broadcast format. The content broadcasted by TVRI must be peaceful, according to facts, not cause divisive effects and must not contain SARA elements in accordance with the Broadcasting Code of Conduct and Broadcast Program Standards (P3 and SPS) issued by KPI. TVRI packages its shows in a balanced way between information, entertainment and education as expressed by Ardison in the following statement:

"TVRI development sector has set a balance way. $40 \%$ information, $30 \%$ education, $30 \%$ entertainment. There must be no too much into entertainment, not too much into education, there must be a balance in that."

One indicator of the success of a television show is the program rating. Rating is an indicator of whether the program has an audience or not (Wulandari, 2015). Based on data from Nielsen Audience Measurement Indonesia (ACNielsen) in 2019, TVRI was in the last rank of 15 television stations with a rating of 0.9 . TVRI as a television station that spreads the values of development actually has a low rating which has an impact on the ineffectiveness of spreading the values of Nawacita and the SDGs. TVRI packages its shows in quality but it can not spread to many audiences so that there needs 
TABLE 2. LPP TVRI Local Stations

\begin{tabular}{|c|c|c|c|c|c|}
\hline No & Local Station & Frequency & No & Local Station & Frequency \\
\hline 1. & TVRI Aceh & $36 \mathrm{UHF}$ & 16. & $\begin{array}{l}\text { TVRI West Nusa Teng- } \\
\text { gara }\end{array}$ & UHF \\
\hline 2. & TVRI North Sumatra & $47 \mathrm{UHF}$ & 17. & TVRI West Kalimantan & $7 \mathrm{VHF}$ \\
\hline 3. & TVRI West Sumatra & $25 \mathrm{UHF}$ & 18. & $\begin{array}{l}\text { TVRI Central Kali- } \\
\text { mantan }\end{array}$ & $29 \mathrm{UHF}$ \\
\hline 4. & TVRI Riau & $8 \mathrm{VHF}$ & 19. & $\begin{array}{l}\text { TVRI South Kaliman- } \\
\qquad \tan \end{array}$ & $40 \mathrm{UHF}$ \\
\hline 5. & TVRI Bengkulu & $48 \mathrm{UHF}$ & 20. & TVRI East Kalimantan & UHF \\
\hline \multirow[t]{2}{*}{6.} & TVRI South Sumatra & $\begin{array}{l}46 \mathrm{UHF} \\
\text { (Analog) }\end{array}$ & 21. & $\begin{array}{l}\text { TVRI North Kaliman- } \\
\tan \end{array}$ & UHF \\
\hline & & $\begin{array}{l}29 \text { UHF } \\
\text { (Digital) }\end{array}$ & & & \\
\hline 7. & $\begin{array}{l}\text { TVRI Bangka Be- } \\
\text { litung }\end{array}$ & $27 \mathrm{UHF}$ & 22. & TVRI South Sulawesi & $37 \mathrm{UHF}$ \\
\hline 8. & TVRI Lampung & $40 \mathrm{UHF}$ & 23. & TVRI North Sulawesi & $45 \mathrm{UHF}$ \\
\hline \multirow[t]{2}{*}{9.} & TVRI West Java & $\begin{array}{l}40 \mathrm{UHF} \\
\text { (Analog) }\end{array}$ & 24. & TVRI Gorontalo & $40 \mathrm{UHF}$ \\
\hline & & $\begin{array}{l}38 \text { UHF } \\
\text { (Digital) }\end{array}$ & & & \\
\hline 10. & TVRI Central Java & $23 \mathrm{UHF}$ & 25. & TVRI Central Sulawesi & $5 \mathrm{VHF}$ \\
\hline 11. & TVRI Jogja & $22 \mathrm{UHF}$ & 26. & TVRI West Sulawesi & $28 \mathrm{UHF}$ \\
\hline \multirow[t]{3}{*}{12.} & TVRI East Java & $\begin{array}{l}9 \text { VHF (Pro } \\
2 \text { ) }\end{array}$ & 27. & TVRI Maluku & UHF \\
\hline & & $\begin{array}{l}26 \mathrm{UHF} \\
\text { (Analog) }\end{array}$ & & & \\
\hline & & $\begin{array}{l}35 \text { UHF } \\
\text { (Digital) }\end{array}$ & & & \\
\hline 13. & TVRI Bali & $29 \mathrm{UHF}$ & 28. & TVRI North Maluku & UHF \\
\hline 14. & $\begin{array}{l}\text { TVRI West Nusa } \\
\text { Tenggara }\end{array}$ & UHF & 29. & TVRI Papua & $44 \mathrm{UHF}$ \\
\hline 15. & TVRI North Maluku & UHF & & & \\
\hline
\end{tabular}


to be a change, especially in terms of packaging of shows. TVRI must combine entertainment and balanced information so that broadcasts can be well received by the public. Nawacita and SDGs as an innovation must be disseminated within a certain period of time and must pass through several stages such as: the knowledge stage, the persuasion stage, the decision stage, the implementation stage and the confirmation stage. The presence of TVRI in the process of disseminating the Nawacita and SDGs, is still in the knowledge and persuasion stages which hampers the implementation of Nawacita and the SDGs.

Another media that TVRI uses in its efforts to realize Nawacita and the SDGs is through the monthly Monitor magazine. Monitor Magazine routinely reports on TVRI activities for one month in the form of internal activities such as training and discussions as well as external activities such as visits and cooperation with several sectors. Monitor Magazine has several rooms that report special content, such as Readers' Letters displaying messages from the public, Management Columns that show the activities of the Board of Directors in building cooperation with various sectors and Event Patterns that display TVRI's broadcast schedule every day for one month. In addition to printed form, Monitor Magazine is also available in digital form which can be downloaded on the official TVRI website.

Monitor magazine is published every month but the publication is often late and will be published when there are special events such as the Asian Games and Asian Paragames. In its content, Monitor Magazine does not specifically discuss Nawacita or SDGs and only discusses development in general. In order to make it easier for readers to understand Nawacita and the SDGs, TVRI should create a special column that highlights the development of Nawacita and the SDGs in Indonesia. In addition, the scope of the Monitor Magazine is not too broad. Monitor magazine is available at the TVRI office which employees can collect free of charge and not distributed to the public. With a reach that is not too broad, the development values contained in the magazine cannot be widely spread. To solve this problem, TVRI created an online version of Monitor Magazine which can be downloaded on the website www.tvri.go.id.

Apart from using mass communication which is able to reach various regions, TVRI also makes use of the use of new media. The use of new media allows the public to be involved and to respond to programs broadcast by TVRI. The new media used by TVRI include website (www. tvri.go.id), Instagram (@tvrinasional with 169 thousand followers as of 23 January 2020), Twitter (@TVRINasional with 102.5 thousand followers as of 23 January 2020), Facebook (TVRI National), Youtube (National TVRI with 190 thousand subscribers as of 23 January 2020) and the application on TVRI Klik which can be downloaded on android as mentioned by Ardison in the following statement:

"As I mentioned, we use multimedia such as website and TVRI Klik, applications in Android. The shows are complete from 29 local channels."

The media used by TVRI is different from Bojonegoro Regency Government which emphasizes interpersonal communication to its citizens. TVRI as a national mass media prioritizes channels spread throughout Indonesia and does not use interpersonal communication. As a national media, TVRI also maximizes the use of social media which increases interaction with netizens. In contrast to 
the research on How Indonesia media deal with Sustainable Development Goals, TVRI did not broadcast specific SDGs goals, but instead packaged them in general so that they could be easily understood by the public.

\section{Instructional Design Strategy by TVRI}

Instructional design strategies are usually used by educators with learning methods with formal learning theories and focus on the development of learning materials such as formative evaluation, trials, and tiered program design. TVRI implemented this strategy by conducting internal and external training to support Nawacita and the SDGs.

Internally, TVRI focuses on providing training through education and training, workshops and technical guidance which provide provisions for employees in certain fields such as journalists, broadcasters and public relations. This training is carried out regularly every year to improve the competence of TVRI employees. Several TVRI employees were given the opportunity to do technical guidance abroad, together with several television stations that collaborated with TVRI as mentioned by Ardison in the following statement:

"The development of our own human resources using training, we have our own training. TVRI training for all professions in the broadcasting field. Secondly, we also attend training abroad, we are also members of the ABD broadcast because there is an association of broadcaster."

The training that has been conducted by TVRI includes the 3rd batch Creative Content (Writing \& Production) Training held by the TVRI Training Center on October 1 - 5, 2018, Digital Video
Broadcasting Terrarian Training Training 2 and Dramatic Script Writing Training on November 25-29 2019 and workshops with the theme Mobile Journalism in Yogyakarta on September 23-27 2019 in collaboration with the Asia-Pacific Institute for Broadcasting Development (AIBD). In addition to conducting internal training for its employees, TVRI through the Puslitbang division also provides external training that can be followed by people who want to get knowledge and certification for the profession of cameraman, presenter, and master of ceremony. The registration process for training can be done at the TVRI office or by contacting $021-5737152$.

The training provided by TVRI did not specifically discuss Nawacita and the SDGs but rather on the development of Human Resources (HR). Human resource development is one of the points in Nawacita and the SDGs so that unconsciously the various training carried out are an effort to realize Nawacita and the SDGs. However, TVRI's training activities are not held regularly, even though the employees have to be equipped with a lot of understanding, including understanding about Nawacita and the SDGs. External training aimed at the general public has also not been going well and has tended to stop in recent years. To improve human resource development and understanding of Nawacita and the SDGs, TVRI must begin to improve its various training programs.

\section{Participatory Strategy by TVRI}

In a participatory strategy, the important principle is in organizing collaborative activities in a community and involving other experienced people (Astuti, 2017). This strategy takes an approach through non-formal education such as training that allows communities or other institutions to exchange information (Ramadhani \& 
Rizky Wulan Ramadhani, dkk. Communication Strategy Development of LPP TVRI...

Prihantoro, 2020). TVRI involves various parties through Jurnalisme Khalayak which provides access to the public to practice citizen journalism. TVRI provides a special space for citizens to conduct citizen journalism through the Jurnalisme Khalayak program which airs every Saturday from 14.00 - 14.30 WIB. Before being broadcast on the program, videos sent by residents must go through a selection process so that the news or information to be broadcast is in accordance with the applicable rules on TVRI. The video that is broadcasted has development values that do not distort people, does not contain SARA elements, contains educational values and displays local wisdom that exists in the community as mentioned by Ardison in the following statement:

"If they send it according to our criteria, it does not demonize people, does not contain SARA elements, contains educational values, whether it is entertainment, we will broadcast."

In increasing public participation to get to know TVRI and the world of broadcasting, TVRI provides opportunities for people to make direct visits to central and regional TVRI studios. The visiting procedure begins by sending a letter to TVRI and TVRI will reply to the letter to inform the schedule of visits. The visit is carried out every week to explain the world of broadcasting on TVRI, the development of the world of broadcasting and to see the production process directly according to national standards. Several institutions that have visited TVRI include the Yayasan Peduli Kasih Anak Berkebutuhan Khusus (YPKABK), the Lembaga Pendidikan dan Pelatihan Polri Sekolah Polisi Wanita and several educational institutions in Indonesia.

By actively involving the audience,
TVRI indirectly enters the social system of society to spread the values of Nawacita and SDGs. Through the Jurnalisme Khalayak program, people demonstrate existing development activities in their areas that are adjusted to local wisdom in their respective regions. The development carried out is infrastructure development and human resource development which is part of Nawacita and the SDGs. By displaying development activities that occur in a social system, the community feels that they are part of national development so that it has an impact on the implementation of Nawacita and the SDGs. In addition, by inviting the public to see production activities at the TVRI office, the public is taught broadcast values in accordance with the Broadcasting Code of Conduct and Broadcast Program Standards (P3 and SPS) issued by KPI as mentioned by Ardison in the following statement:

"...apart from being given
an explanation of the world
of broadcasting on TVRI, the
development of the world of
broadcasting, they can also see
it directly in the studio to see the
production process."

TVRI has not maximized the role of the community, Non-Governmental Organizations (NGO), and Civil Society Organizations (CSO) in providing information related to Nawacita and SDGs as has been done by the Bojonegoro Regency Government. Their role is important to be broadcast on television stations because they consistently implement the specific objectives of the SDGs in the field. TVRI has aired community activities several times but did not discuss the values of Nawacita and the SDGs in depth. Thus, the participatory strategy carried out by TVRI can be improved by actively 
involving communities or NGOs in an effort to implement Nawacita and the SDGs in Indonesia.

\section{Marketing Strategy by TVRI}

As a government media partner in broadcasting various educational and entertaining shows, TVRI is committed to packaging broadcast programs in accordance with the Broadcasting Code of Conduct and Broadcast Program Standards (P3 and SPS) issued by KPI. In addition, the content broadcast by TVRI has a public value to serve every level of society in order to receive information, education and entertainment that builds people's lives better, creates peace, is in accordance with the facts, and does not have a divisive effect. As a national television station, TVRI offers programs to carry out development in order to make Nawacita and SDGs a success. This development is realized through balanced content containing 40\% information, $30 \%$ education, and $30 \%$ entertainment combined with cultural values, eastern Indonesian values that are expected to be able to maintain unity and integrity, motivate people to work and improve public education.

TVRI programs are not only broadcast in big cities like Jakarta and Surabaya. Through the development of infrastructure and digital transmitters, TVRI is able to reach all communities to the frontier, outermost and disadvantaged (3T) borders and areas. So far, TVRI is the television station with the highest number of transmitters with 372 analog and digital transmitters that are evenly distributed in Indonesia. TVRI is able to reach $68 \%$ of the population or more than 200 million Indonesians and presents a variety of balanced shows. TVRI is a public broadcasting institution, one of the state-owned national televisions and the first television that can broadcast in Indonesia, which has a major influence in providing useful development information for the community (Ningsih, 2017).

Some TVRI programs that have the value of Nawacita and SDGs development include Kukuruyuk which provides education about English which airs every day at 05.45 WIB, English News Service which broadcasts news in English format, Melayani Indonesia which broadcasts marginalized groups, Jendela Dunia broadcasts the life of the community abroad, Dari Desa ke Desa which shows the various life and developments of the villages and Pesona Indonesia which shows the various lives, cultures and uniqueness of various regions in Indonesia. From these programs, TVRI received various awards both nationally and internationally, such as the KPI Award for Quality Broadcasting for Child Friendly TV Stations, MUI for the Best Syiar Ramadhan Television Station, BAZNAS Award for Awakening of Zakat through Electronic Media, Ministry of Transportation for 2018 Homecoming Coverage, and Asia. -Pacific Broadcasting Union News Ferry Reversed at Lake Toba Asia Vision Monthly Award.

TVRI programs are independent and quality programs in order to make Nawacita and SDGs a success, which are packaged in various formats such as music, religion, entertainment, art, culture and education programs. These programs are broadcast every day with a duration of 30 minutes to an hour which is arranged according to the program pattern based on the characteristics, patterns and conditions of the audience as mentioned by Ardison in the following statement:

"Yes, in the content, every day it still
leads to that direction (Nawacita
dan SDGs). It's just that we can't
give educational programs from
morning to evening, no. There is
an arrangement of the program's 
Rizky Wulan Ramadhani, dkk. Communication Strategy Development of LPP TVRI...

pattern, yes, it is arranged in such a way based on the characteristics of the audience."

The increasingly rapid and competitive development of television media has led to competition from various television media in presenting increasingly varied programs in television program formats and content in order to attract more public attention (Kurniawati, 2019). TVRI programs emphasize cultural, educational and entertainment values. It is very important for TVRI to continue broadcasting programs that are truly out of date for the current era, boring for millennials because the content on TVRI shows mingles about culture, education and entertainment (Diharyo \& Sari, 2019). TVRI needs to develop its program to make it attractive but still spread the values of development in accordance with Nawacita and the SDGs.

Apart from broadcasting programs, TVRI's marketing strategy is also carried out through the cooperation of various parties to mutually benefit the parties concerned as well as having an impact on the audience. The collaboration carried out by TVRI, among others, with the Indonesian Institute of Sciences (LIPI) on the dissemination of information on research results, development and utilization of science and technology which will be broadcast on TVRI programs for the enjoyment of the Indonesian people. TVRI collaborated with the National Zakat Agency (BAZNAS) to collect donations for victims of the earthquake and tsunami in Central Sulawesi in September last year. This collaboration is a form of concern for TVRI and BAZNAS for victims who have suffered material losses.

Helmy Yahya with Syafrudin, Minister of StateApparatus Empowerment and Bureaucratic Reform (PANRB) signed a memorandum of understanding regarding the publication of information services for the utilization of state apparatus. This signing is expected to be able to produce cooperation in an effort to convey more accurate information to the public. TVRI also collaborates with various international TV stations such as Voice of America (VOA), Associated Press (AP), News Agency, Nickelodeon, WITN22 Parliament TV and NSR Entertainment to learn from each other and exchange programs.

Various development communication strategies carried out by TVRI can be a reference for mass media and other online media to increase their role in realizing Nawacita and SDGs in Indonesia. The media-based strategy used can be adapted to the type of media used to disseminate the aims of the Nawacita and SDGs in general and specifically. Instructional design strategies can be used by carrying out training for employees and the community to increase human resource capabilities which will have an impact on improving their standard of living. Participatory strategies can be used by increasing the role of the community, community, NGOs, and CSOs that are actively involved in the realization of Nawacita and the SDGs. By involving them, other parties can emulate so that Nawacita and the SDGs can be carried out carefully.

\section{CONCLUSION}

From this research it can be concluded that (1) The role of mass media and new media is helping in the successful implementation of Nawacita and SDGs in Indonesia; (2) TVRI as a public broadcasting institution helps to succeed and contribute greatly to the implementation of Nawacita and SDGs in Indonesia; (3) The development communication strategy can be used by mass media and new media to spread the values of Nawacita and the SDGs 
in Indonesia. The findings of this study are that the communication strategy development undertaken by TVRI can be a reference for other media in the successful implementation of Nawacita and SDGs in Indonesia. This is important because the media plays a role in shaping public understanding of Nawacita and the SDGs in Indonesia.

The role of mass media, namely television, in development is indeed effective because it still plays a major role in conventional media. However, seeing the trend of communication media that has developed with the new media, TVRI must also follow the current trend of communication media. Researchers suggest that TVRI optimize both mass media and converged new media in order to reach a broad audience and hopefully have a greater influence so that the SDGs and Nawacita programs are well disseminated. In addition, TVRI must also improve the quality of its programs so that more audiences are interested in implementing Nawacita and the SDGs.

\section{REFERENCE}

ACSC. (2016). The Roles of Civil Society in Localising the Sustainable Development Goals (Issue March).

Angelica, X., \& Nurhajati, L. (2019). Framing Media Online atas Pemberitaan Isu Lingkungan Hidup Dalam Upaya Pencapaian Keberhasilan SDGs Indonesia. 3(1), 14-23.

Arianto, Z. (2019). Upaya Pemerintahan Joko Widodo dalam Mendorong Implementasi Sustainable Development Goals di Indonesia.

Astuti, R. (2017). Strategi Komunikasi Pembangunandalam Mempertahankan Pasar Tradisional Sentral Benteng di Kabupaten Kepulauan Selayar. Universitas Islam Negeri (UIN) Alauddin Makassar.

Azhar. (2017). KOMUNIKASI ANTARPRIBADI: Suatu Kajian dalam Perspektif Komunikasi Islam. Jurnal Al-Hikmah, IX(14), 79-91.
Batubara, F. A. (2018). DESAIN INSTRUKSIONAL ( Kajian Terhadap Komponen Utama Strategi Instruksional dan Penyusunannya). III(2), 657-667.

Diharyo, J., \& Sari, W. P. (2019). Eksistensi LPP TVRI Dalam Industri Penyiaran. Jurnal Prologia, 3(1), 162-168.

Elizabeth, A. F., \& Olayemi, A. W. (2020a). Influence of Mass Media on Sustainable Development Goal One Attainment in Osun State. American Journal of Social Sciences and Humanities, 5(1), 1-16. https://doi.org/10.20448/801.51.1.16

Elizabeth, A. F., \& Olayemi, A. W. (2020b). Influence of Mass Media on Sustainable Development Goal One Attainment in Osun State Influence of Mass Media on Sustainable Development Goal One Attainment in Osun State , Nigeria. November 2019. https://doi. org/10.20448/801.51.1.16

Hendra, T. (2019). Media Massa Dalam Komunikasi Pembangunan. JURNAL AT-TAGHYIR, 1(2), 136-152.

Istiati, F. (2016). Difusi Inovasi Dalam Kegiatan Komunikasi Pembangunan (Studi DeskriptifKualitatif Terhadap Program Bantuan Bibit Gratis oleh Persemaian Permanen Balai Pengelola Daerah Aliran Sungai dan Hutan Lindung Serayu Opak Progo Yogyakarta pada Masyarakat Desa Gading. Universitas Islam Negeri Sunan Kalijaga Yogyakarta.

Khatimah, H. (2018). Posisi dan peran media dalam kehidupan masyarakat. 16(1).

Kumar, D., \& Tyagi, P. (2017). New Media and Sustainable Development in India. 6(3), 447-454.

Kurniawati, L. (2019). Implikasi standar program siaran pada tayangan edukasi dan artistik TVRI Jawa Barat. Jurnal ProTVF, 3(2), 141-154.

Ningsih, F. (2017). Peran Televisi Republik Indonesia (TVRI) dalam Memenuhi Kebutuhan Informasi Pembangunan di Kecamatan Sungai Kunjang (Studi Kasus pada TV Regional Kaltim). EJournal Ilmu Komunikasi, 5(2), 150159.

Nurwanda, A., \& Badriah, E. (2020). Analisis Program Inovasi dalam Mendorong 
Rizky Wulan Ramadhani, dkk. Communication Strategy Development of LPP TVRI...

Pengembangan Ekonomi Lokal oleh Tim Pelaksana Inovasi Desa (PID) di Desa Bangunharja Kabupaten Ciamis. Jurnal Ilmiah Ilmu Administrasi Negara, 7(1), 68-75.

Panuluh, S., \& Fitri, M. R. (2016). Briefing Paper 02 Perkembangan Pelaksanaan Sustainable Development Goals ( $S D G s$ ) di Indonesia (Issue September). Pardo, C. P. (2018). Proactive Civil Society to Achieve SDGs. European Journal of Sustainable Development, 7(4), 6370. https://doi.org/10.14207/ejsd.2018. v7n4p63

Putri, G. E. (2017). Difusi Inovasi Program Pajak E-Filing (Studi Deskriptif Kualitatif Dengan Pendekatan Teori Difusi Inovasi Program Pajak e-filing Kantor Radio Republik Indonesia di Surakarta) Disusun. Universitas Muhammadiyah Surakarta.

Qudratullah. (2016). Peran dan Fungsi Komunikasi Massa. Jurnal Tabligh, 41-46.

Said, A., Budiati, I., Reagan, H. A., Riyadi, Hastuti, A., Anam, C., Larasaty, P., Setiyawati, N., Hardika, B., Agusta, M. W., Arifin, M., Andriastuti, R. D., \& Tama, D. (2016). Potret Awal Tujuan Pembangunan Berkelanjutan (Sustainable Development Goals) di Indonesia.

Samatan, N. (2017). Riset Komunikasi 1 (Edisi Pert). Penerbit Gunadarma.
Surahmi, A., \& Farid, H. M. (2018). Strategi Komunikasi Dalam Meningkatkan Partisipasi Masyarakat Terhadap Pembangunan di Kecamatan Duampanua Kabupaten Pinrang. Jurnal Komunikasi Kareba, 7(2), 232-239. https://doi.org/http://dx.doi. org/10.31947/kareba.v7i2.6959

Suri, D. (2019). Pemanfaatan Media Komunikasi dan Informasi dalam Perwujudan Pembangunan Nasional. 17(2), 177-187.

Watie, E. D. S. (2011). Komunikasi dan Media Sosial ( $\mathrm{C}$ ommunications and Social Media ). The Messenger, III(1), 69-75.

Wulandari, T. A. (2015). Mendongkrak Keberhasilan Program Televisi di Indonesia Melalui Akun pada Situs Jejaring Sosial Twitter. Jurnal Ilmu Politik Dan Komunikasi, V(2).

\section{ACKNOWLEDGEMENT}

Thank you to Mr. Ardison as the Head of Program and News Review of the Center for Research and Development of the LPP TVRI for taking his time to become the key informant of this research. Thanks to Gunadarma University for supporting the research. 